\title{
ANALISIS FAKTOR-FAKTOR YANG MEMPENGARUHI KINERJA SATGAS KEBERSIHAN DI DINAS LINGKUNGAN HIDUP KABUPATEN BALANGAN
}

\author{
Erwin Rizafana* \\ Sekolah Tinggi Ilmu Ekonomi Pancasetia \\ Jl. Ahmad Yani Km. 5.5 Banjarmasin \\ erwinlh.sanggam@gmail.com
}

\begin{abstract}
Abstrak : Erwin Rizafana Npm.1711.32202.4664, Analisis Faktor-Faktor Yang Mempengaruhi Kinerja Satgas Kebersihan Di Dinas Lingkungan Hidup Kabupaten Balangan, Dibawah Bimbingan Lanny Purnama Kosasi Dan Yudi Rahman, 2020. Tujuan yang ingin dicapai dalam penelitian ini adalah untuk mengetahui dan menganalisis pengaruh faktor individu, faktor psikologi dan faktor organisasi secara parsial terhadap kinerja pegawai Satgas Kebersihan, untuk mengetahui dan menganalisis pengaruh faktor individu, faktor psikologi dan faktor organisasi secara simultan terhadap kinerja pegawai dan untuk mengetahui dan menganalisis diantara faktor individu, faktor psikologi dan faktor organisasi yang berpengaruh dominan terhadap kinerja pegawai Satgas Kebersihan di Dinas Lingkungan Hidup Kabupaten Balangan. Populasi dalam penelitian ini adalah satgas kebersihan Dinas Lingkungan Hidup Kabupaten Balangan yang berjumlah sebanyak 145 Orang dan sampel penelitian dengan jumlah 31 responden atau sebanyak $22 \%$ dari jumlah populasi dan metode yang digunakan dalam pengambilan sampel penelitian ini menggunakan metode sensus. Jenis data, merupakan penelitian asosiatif dengan paradigma kuantitatif dengan aplikasi SPSS dan analisis regresi berganda. Hasil penelitian hipotesis pertama diketahui faktor individu, faktor psikologi dan faktor organisasi berpengaruh signifikan secara parsial terhadap kinerja pegawai Satgas Kebersihan, pengujian hipotesis kedua diketahui faktor individu, faktor psikologi dan faktor organisasi berpengaruh signifikan secara simultan terhadap kinerja pegawai Satgas Kebersihan dan pengujian hipotesis ketiga diketahui bahwa hasil penelitian yang menguji secara parsial dinyatakan dan dibuktikan dalam penelitian ini bahwa faktor psikologi berpengaruh dominan terhadap kinerja pegawai Satgas Kebersihan di Dinas Lingkungan Hidup Kabupaten Balangan.
\end{abstract}

\section{Kata Kunci : Faktor Individu, Faktor Psikologi, Faktor Organisasi Dan Kinerja}

\section{PENDAHULUAN}

\subsection{Latar Belakang Masalah}

Keberadaan Peraturan Pemerintah tentang pemberian kewenangan dalam bidang kepegawaian ini perlu diimbangi dengan penataan manajemen dan kelembagaan yang mengelola sumber daya aparatur, karena kelancaran pelaksanaan tugas organisasi ini sangat tergantung pada kesempurnaan dari pegawai yang berada didalamnya yang mampu bekerja secara profesional, efektif dan efisian guna meningkatkan kelancaran roda pemerintahan. Pegawai merupakan salah satu faktor penting penentu kemajuan suatu organisasi. Menurut Thomson (1996) dalam Robbins (2010:264) menjelaskan kualitas organisasi bergantung pada kualitas orangorang yang ada didalamnya. Untuk mendapatkan pegawai yang produktif dan berprestasi dalam bekerja organisasi dituntut untuk memiliki alat timbal balik yang sesuai dengan kinerja masing-masig pegawai, demi mendapatkan pegawai yang produktif dan kinerja terbaik sesuai harapan dan tujuan organisasi. Menurut Wibowo, (2011:76) ada tiga faktor yang dapat mempengaruhi kinerja seseorang antara lain (1) faktor individu, menyangkut kemampuan yang dimiliki karyawan dalam bekerja, keterampilan yang baik dimiliki karyawan saat bekerja, latar belakang keluarga, seperti budaya keluarga yang suka kerja, pengalaman tingkat sosial, yaitu adanya pengelaman dalam bersialisasi dalam pekerjaan yang baik, demografi seseorang, bentuk kesukuan dari karyawan yang mempengaruhi karyawan bekerja 
lebih baik (2) faktor psikologis, yaitu persepsi, yaitu pandangan yang baik dari seorang karyawan terhadap pekerjaan, peran, adanya peran positif dalam bekerja menunjang aktivitas kerja karyawan, sikap, adalah suatu bentuk perilaku yang baik terhadap pekerjaan, kepribadian, karyawan mempunyai kepribadian yang baik terhadap pekerjaannya, motivasi, seorang karyawan mempunyai motivasi yang tinggi dalam bekerja dan kepuasan kerja, seorang karyawan mempunyai kepuasan yang baik dalam bekerja (3) faktor organisasi, yaitu menyangkut struktur organisasi, dalam hal ini struktur organisasi memberikan alur tanggungjawab yang baik terhadap karyawan dalam bekerja, desain pekerjaan, adanya penempatan pekerjaan sesuai dengan bidang dan keahlian, kepemimpinan, dalam hal ini gaya seorang pemimpin yang baik dalam memimpin organisasi dan bawahannya. dan sistem penghargaan, dalam hal ini perusahaan memberikan adanya penghargaan terhadap karyawan yang berprestasi. Sehubungan dengan hal tersebut Dinas Lingkungan Hidup Kabupaten Balangan merupakan salah satu instansi pemerintah daerah mempunyai komitmen untuk mengembangkan, merumuskan, menyusun, menyelenggarakan, koordinasi, monitoring kebijakan bidang pengelolaan sumber daya alam, pengendalian, pencemaran dan kerusakan lingkungan hidup. Dinas Lingkungan Hidup Kabupaten Balangan selama ini masih keterbatasan akan tenaga pegawai operasional yang bertugas melaksanakan kebersihan maupun pengelolaan akan sampah (Satgas Kebersihan), sehingga pihak Dinas Lingkungan Hidup Kabupaten Balangan banyak menerima dan mengangkat tenaga/pegawai kontrak guna menunjang kegiatan operasional tersebut. Bila dilihat dari aspek individu pegawai kontrak/ satgas kebersihan selama ini terdapat beberapa masalah dan kendala selama ini mereka memiliki pendidikan dan pola pikir yang berbeda satu dengan yang lainnya, sehingga kerap kali membuat mereka rendah diri dalam bekerja, selain itu mereka merasakan penghasilan yang mereka terima belum dapat memenuhi kebutuhan mereka baik menyangkut kelancaran dalam pemberian gaji atau bentuk lainnya, sehingga aspek ini terkadang membuat aktivitas kerja mereka menjadi kurnag optimal. Secara psikologi sehingga setiap satgas kebersihan di Dinas Lingkungan Hidup Kabupaten Balangan merasa terbebani dalam bekerja, selain itu mereka berpikir akan lebih termotivasi dalam bekerja mengingat kesejahteraannya dapat terpenuhi dan diterima sesuai dengan haknya. Selain itu sebagian satgas kebersihan mempunyai pandangan kurang baik dalam bekeja sehingga peran positif dalam bekerja menjadi menurun ditambah lagi masih terlihat perilaku mereka dalam bekerja yang selalu menunggu perintah. Sedangkan dari aspek organisasi selama ini pihak instansi Dinas Lingkungan Hidup Kabupaten Balangan kerap kali memberikan alur tanggungjawab, desain pekerjaan serta dalam penempatan pekerjaan tidak sesuai dengan bidang dan keahlian mereka, sehingga berpengaruh terhadap kinerja satgas kebersihan. Selain itu juga Dinas Lingkungan Hidup Kabupaten Balangan dihadapkan pula oleh adanya tuntutan dari para pegawai kontrak tersebut mengharapkan sekali adanya perubahan terhadap status mereka, karena mereka berharap dianggakat menjadi pegawai tetap atau PNS dari sekian banyak pekerja kebersihan tersebut ada yang mempunyai masa kerja yang sudah cukup lama, namun status mereka hanya terpaku pada status kontrak saja, pihak instansi terkait kurang memperhatikan inspirasi dari para pegawai kontrak tersebut, sehingga berdasarkan dari adanya ketidakpuasan akan rendahnya tingkat kesejahteraan yang didapat, tingginya beban kerja yang dihadapi serta beluam adanya realisasi pengangkatan menjadi pegawa tetap sehingga hal ini secara langsung berdampak terhadap kinerja para pegawai menjadi kurang optimal seperti kurang disiplin dalam bekerja dan menyelesaikan pekerjaan kerap kali lambat selalu nunggu perintah dan terkesan asal-asalan atau tidak mempunyai rencana kerja yang jelas.

Berdasarkan hal itulah, maka penulis tertarik untuk mengangkat permasalahan 
tersebut kedalam sebuah penelitian dengan judul Analisis Faktor-faktor Yang Mempengaruhi Kinerja Satgas Kebersihan di Dinas Lingkungan Hidup Kabupaten Balangan.

\section{umusan Masalah}

Terkait dengan uraian dari latar belakang permasalahan yang dikemukakan sebelumnya, maka adapun yang menjadi perumusan masalah dalam penelitian ini, yaitu :

Apakah faktor individu, faktor psikologi dan faktor organisasi berpengaruh signifikan secara parsial terhadap kinerja pegawai Satgas Kebersihan di Dinas Lingkungan Hidup Kabupaten Balangan? Apakah faktor individu, faktor psikologi dan faktor organisasi berpengaruh signifikan secara simultan terhadap kinerja pegawai Satgas Kebersihan di Dinas Lingkungan Hidup Kabupaten Balangan?

Manakah diantara faktor individu, faktor psikologi dan faktor organisasi yang berpengaruh dominan terhadap kinerja pegawai Satgas Kebersihan di Dinas Lingkungan Hidup Kabupaten Balangan?

\section{TINJAUAN PUSTAKA}

\subsection{Landasan Teori}

\subsubsection{Faktor Individu}

Secara etimologis, kata "individu" diadaptasi dari bahasa Inggris yang berasal dari bahasa Yunani "individium", dimana artinya "tidak terbagi". Istilah tersebut merujuk pada suatu kesatuan yang paling kecil dan terbatas. Sehingga dalam hal ini, individu merupakan suatu kesatuan yang terbatas, yaitu sebagai manusia perseorangan bukan sebagai manusia keseluruhan. Menurut Hartomo (2013:90), terdapat 3 aspek yang melekat pada individu dan saling berhubungan satu dengan lainnya, yaitu; aspek organik jasmaniah, aspek psikis-rohaniah dan aspek sosial. Suatu masyarakat merupakan latar belakang keberadaan identitas individu. Pada perkembangannya, individu tersebut mengalami sejumlah bentuk sosialisasi sehingga dapat mengembangkan tiga aspek individu (organik jasmaniah, psikisrohaniah, sosial) di dalam dirinya. Menurut Luther (1990) dalam Muchtar (2011:124), pengertian individu adalah satuan kecil yang tidak dapat dibagi lagi, yaitu manusia yang hidup berdiri sendiri. Individu sebagai mahkluk ciptaan tuhan di dalam dirinya selalu dilengkapi oleh kelengkapan hidup yang meliputi raga, rasa, rasio, dan rukun. Menurut Soekanto, (2013:231), arti individu adalah makhluk hidup ciptaan Tuhan yang di dalam dirinya dilengkapi oleh kelengkapan hidup yang meliputi raga, ras, dan rukun. Individu merupakan unit terkecil pembentuk masyarakat. Syani (2012: 25), kata individu berasal dari bahasa Yunani "individum" yang artinya satuan terkecil yang tidak dapat dibagi lagi. Manusia sebagai individu memiliki karakteristik yang unik dan berbeda-beda. Menurut John, Donahue, dan Kentle dalam Darmwan (2012:112), terdapat 5 karakteristik individu, yaitu:

Openness to Experience: yaitu karakteristik individu yang terbuka terhadap pengalaman baru, baik berupa ide maupun imajinasi. Umumnya individu yang memiliki karakter ini suka berpikir secara mendalam, cerdik, kreatif, artistik, memiliki rasa penasaran tinggi, inovatif, dan sering merefleksikan diri.

Conscientiousness: yaitu karakteristik individu yang sangat berhati-hati dan penuh pertimbangan dalam melakukan suatu tindakan. Umumnya individu dengan karakter ini memiliki disiplin yang tinggi, rajin, dapat diandalkan, bertanggungjawab, serta bekerja dengan cermat dan terperinci. Extraversion: yaitu karakteristik individu yang terbuka dan nyaman bila berinteraksi dengan orang lain. Umumnya individu dengan karakter ini senang bergaul, ramah, antusias, mudah bersosialisasi, dan tegas.

Agreeableness: yaitu karakter individu yang kooperatif dan selalu ingin menghindari konflik terbuka dengan orang lain. Umumnya individu dengan karakter ini suka menolong, tidak egois, bisa dipercaya, penuh perhatian, dan tidak menyukai perselisihan.

Neocritism: yaitu karakteristik individu yang terbuka terhadap tekanan dan menilai kemampuan seseorang dalam menahan stress.

\subsubsection{Faktor Psikologi}


Secara etimologis istilah "psikologi" berasal dari bahasa latin, yaitu "psyche" yang artinya jiwa dan "logos" yang artinya pengetahuan. Sehingga pengertian psikologi dapat didefinisikan sebagai ilmu yang mempelajari kejiwaan, baik manusia maupun organisme lainnya. Syah (2012:9), pengertian psikologi adalah ilmu pengetahuan yang mempelajari tentang tingkah laku terbuka (berbicara, duduk, berjalan, dan lainnya) dan tingkah laku tertutup (berfikir, berkeyakinan, berperasaan) pada manusia, baik selaku individu maupun kelompok, dalam hubungannya dengan lingkungan. Wilhem Wundt (1999) dalam Jarmain (2013:11) pengertian psikologi adalah suatu ilmu yang mempelajari tentang berbagai pengalaman yang terjadi pada manusia; seperti perasaan panca indera, perasaan, pikiran, dan kehendak. Menurut Kurt Koffka (1997) dalam Jarmain (2013:10) pengertian psikologi adalah suatu ilmu pengetahuan yang mempelajari tentang perilaku mahluk hidup dalam hubungan mereka dengan dunia luar. Singgih (2011:7) definisi psikologi adalah suatu ilmu yang mempelajari tentang tingkah laku manusia. Menurut KBBI (2012), pengertian psikologi adalah ilmu pengetahuan yang berhubungan dengan proses mental, baik normal maupun abnormal dan pengaruhnya terhadp perilaku organisme. Psikologi dapat juga didefinisikan sebagai ilmu pengetahuan tentang gejala dan kegiatan jiwa.

\subsubsection{Faktor Organisasi}

Menurut Stoner pengertian organisasi adalah sebuah pola hubungan-hubungan melalui mana orang-orang di bawah pengarahan atasan untuk mencapai tujuan bersama Menurut Stephen P. Robbins dalam As'ad, (2011:90) pengertian organisasi adalah kesatuan (entity) sosial yang dikoordinasikan secara sadar, dengan sebuah batasan yang relatif dapat diidentifikasi, yang bekerja atas dasar yang relatif terus menerus untuk mencapai suatu tujuan bersama atau sekelompok tujuan. Menurut James D. Mooney dalam Mangkunegara, (2012:132) pengertian organisasi adalah bentuk setiap perserikatan manusia untuk mewujudkan tujuan bersama.

Menurut Hasibuan (2012:90) pengertian organisasi adalah sebagai proses penentuan, pengelompokan, dan pengaturan bermacam-macam aktivitas yang diperlukan untuk mencapai tujuan bersama. Menurut Siagian (2011:88) pengertian organisasi adalah setiap bentuk persekutuan antara dua orang / lebih yang saling bekerjasama serta terikat secara formal dalam rangka melakukan pencapaian tujuan yang sudah ditentukan dalam ikatan yang ada pada seseorang atau beberap orang yang dikenal sebagai atasan dan seorang atau kelompok orang yang dikenal sebagai bawahan.

Siagian (2011:95) ada beberapa manfaat organisasi yang bisa dirasakan oleh para anggotanya, diantaranya adalah

Memudahkan tercapainya tujuan bersama

Melatih mental seseorang agar lebih baik

Memudahkan pemecahan masalah

Melatih kepemimpinan seseorang

Pergaulan menjadi lebih luas

Menambah wawasan para anggota organisasi

Membentuk karakter seseorang

Ajang pembelajaran bagi para anggota

\subsubsection{Faktor Kinerja}

Kinerja pada dasarnya adalah apa yang dilakukan atau tidak dilakukan pegawai. Kinerja pegawai adalah yang mempengaruhi seberapa banyak mereka memberi kontribusi kepada organisasi. Perbaikan kinerja baik untuk individu maupun kelompok menjadi pusat perhatian dalam upaya meningkatkan kinerja organisasi. Shandy (2012:104) mengungkapkan bahwa kinerja adalah kemamapuan seseorang menyelesaikan tugas dengan atau tanpa alat yang menggambarkan suatu prestasi kerja. Dewantara (2011:78) kinerja adalah merupakan kata benda. salah satu entry-nya adalah "thing done" (sesuatu hasil yang telah dikerjakan). Jadi arti kinerja adalah hasil kerja yang dapat dicapai oleh seseorang atau kelompok orang dalam suatu organisasi, sesuai dengan wewenang dan tanggung jawab masing-masing dalam rangka upaya mencapai tujuan organisasi 
bersangkutan secara legal,tidak melanggar hukum dan sesuai dengan moral maupun etika. Menurut Muchtar (2011:56) berpendapat bahwa kinerja merupakan hasil kerja yang dihasilkan oleh pegawai atau perilaku nyata yang ditampilkan sesuai peranannya dalam organisasi. Kinerja juga berarti hasil yang dicapai seseorang baik kualitas maupun kuantitas sesuai dengan tanggungjawab yang diberi kepadanya. Selain itu kinerja seseorang dipengaruhi oleh tingkat pendidikan, inisiatif, pengalaman kerja, dan motivasi karyawan. Hasil kerja seseorang akan memberikan umpan balik bagi orang itu sendiri untuk selalu aktif melakukan pekerjaannya secara baik dan diharapkan akan menghasilkan mutu pekerjaan yang baik pula. Pendidikan mempengaruhi kinerja seseorang karena dapat memberikan wawasan yang lebih luas untuk berinisiatif dan berinovasi dan selanjutnya berpengaruh terhadap kinerjanya. Kinerja atau prestasi kerja diberi batasan oleh Maier (dalam As'ad,2001:47) sebagai kesuksesan seseorang didalam melaksanakan suatu pekerjaan. Lebih tegas lagi Lawler dan Poter menyatakan bahwa kinerja adalah "Succesful Role Achievement" yang diperoleh seseorang dari perbuatanperbuatannya. Dari batasan tersebut as'ad meyimpulkan bahwa kinerja adalah hasil yang dicapai seseorang menurut ukuran berlaku untuk pekerjaan bersangkutan. Menurut Muchtar (2011:56) berpendapat bahwa kinerja merupakan hasil kerja yang dihasilkan oleh pegawai atau perilaku nyata yang ditampilkan sesuai peranannya dalam organisasi. Kinerja juga berarti hasil yang dicapai seseorang baik kualitas maupun kuantitas sesuai dengan tanggungjawab yang diberi kepadanya. Selain itu kinerja seseorang dipengaruhi oleh tingkat pendidikan, inisiatif, pengalaman kerja, dan motivasi karyawan. Hasil kerja seseorang akan memberikan umpan balik bagi orang itu sendiri untuk selalu aktif melakukan pekerjaannya secara baik dan diharapkan akan menghasilkan mutu pekerjaan yang baik pula. Pendidikan mempengaruhi kinerja seseorang karena dapat memberikan wawasan yang lebih luas untuk berinisiatif dan berinovasi dan selanjutnya berpengaruh terhadap kinerjanya. Kinerja (performance) dengan prestasi kerja yaitu proses melalui mana organisasi mengevaluasi atau menilai prestasi kerja karyawan. Menurut Winardi (2002:67) kinerja merupakan konsep yang bersifat universal yang merupakan efektivitas operasional suatu organisasi, bagian organisasi dan bagian karyawannya berdasar standar dan kriteria yang telah ditetapkan sebelumnya, karena organisasi pada dasarnya dijalankan oleh manusia, maka kinerja sesungguhnya merupakan perilaku manusia dalam memainkan peran yang mereka lakukan dalam suatu organisasi untuk memenuhi standar perilaku yang telah ditetapkan agar membuahkan tidakan dan hasil yag diinginkan.

Efendi (2002) berpendapat bahwa kinerja merupakan hasil kerja yang dihasilkan oleh pegawai atau perilaku nyata yang ditampilkan sesuai peranannya dalam organisasi. Kinerja juga berarti hasil yang dicapai seseorang baik kualitas maupun kuantitas sesuai dengan tanggungjawab yang diberi kepadanya. Selain itu kinerja seseorang dipengaruhi oleh tingkat pendidikan, inisiatif, pengalaman kerja dan motivasi karyawan. Hasil kerja seseorang akan memberikan umpan balik bagi orang itu sendiri untuk selalu aktif melakukan pekerjaannya secara baik dan diharapkan akan menghasilakn mutu pekerjaan yang baik pula. Pendidikan mempengaruhi kinerja seseorang karena dapat memberikan wawasan yang lebih luas untuk berinisiatif dan berinovasi dan selanjutnya berpengaruh terhadap kinerjanya. Menurut Gomes (2000:11) kinerja merupakan catatan terhadap hasil produksi dari sebuah pekerjaan tertentu atau aktifitas tertentu alam periode waktu tertentu. Mangkunegara (2012:67) kinerja adalah hasil kerja secara kualitas dan kuantitas yang dicapai oleh seorang pegawai dalam melaksanakan tugasnya sesuai dengan tanggung jawab yang diberikan kepadanya. Tinggi rendahnya kinerja pekerja berkaitan erat dengan sistem pemberian penghargaan yang diterapkan oleh lembaga/organisasi tempat mereka bekerja. Pemberian 
penghargaan yang tidak tepat dapat berpengaruh terhadap peningkatan kinerja seseorang. Berkaitan erat dengan kinerja pegawai dalam melaksanakan tugasnya sehari-hari sehingga dalam melaksanakan tugasnya perlu memiliki tiga kemampuan dasar agar kinerjanya tercapai sebagai berikut:

Kemampuan pribadi meliputi hal-hal yang bersifat fisik seperti tampang,suara, mata atau pandangan, kesehatan, pakaian, pendengaran, dan hal yang bersifat psikis seperti humor, ramah, intelek, sabar, sopan, rajin,kreatif, kepercayaan diri, optimis, kritis, obyektif, dan rasional.

Kemampuan sosial antara lain bersifat terbuka, disiplin, memiliki dedikasi,tanggung jawab, suka menolong, bersifat membangun, tertib, bersifat adil, pemaaf, jujur, demokratis, dan cinta anak didik.

Kemampuan profesional sebagaimana dirumuskan oleh P3G

Menurut Setiawan (2012:88) mengungkapkan bahwa "kinerja adalah kemampuan seseorang menyelesaikan tugas dengan atau tanpa alat yang menggambarkan suatu prestasi kerja. Selain itu Evalia (2010:70) definisi dari kinerja adalah hasil kerja secara kualitas dan kuantitas yang dicapai oleh seorang pegawai dalam melaksanakan tugasnya sesuai dengan tanggung jawab yang diberikan kepadanya. Tinggi rendahnya kinerja pekerja berkaitan erat dengan sistem pemberian penghargaan yang diterapkan oleh lembaga/organisasi tempat mereka bekerja. Pemberian penghargaan yang tidak tepat dapat berpengaruh terhadap peningkatan kinerja seseorang. Berkaitan erat dengan kinerja pegawai dalam melaksanakan tugasnya sehari-hari sehingga dalam melaksanakan tugasnya perlu memiliki tiga kemampuan dasar agar kinerjanya tercapai sebagai berikut, kemampuan pribadi meliputi hal-hal yang bersifat fisik seperti tampang,suara, mata atau pandangan, kesehatan, pakaian, pendengaran, dan hal yang bersifat psikis seperti humor, ramah, intelek, sabar, sopan, rajin,kreatif, kepercayaan diri, optimis, kritis, obyektif, dan rasional. kemampuan sosial antara lain bersifat terbuka, disiplin, memiliki dedikasi,tanggung jawab, suka menolong, bersifat membangun, tertib, bersifat adil, pemaaf, jujur dan demokratis. Dan kemampuan professional. Dessler (2007:102) menyatakan bahwa penilaian kinerja adalah memberikan umpan balik kepada karyawan dengan tujuan memotivasi para pegawai untuk menghilangkan/meminimalkan

kemerosotan kinerja/berkinerja lebih tinggi lagi. Dessler, penilaian kerja terdiri dari tiga langkah, pertama mendifinisikan pekerjaan berarti memastikan bahwa atasan dan bawahan sepakat dengan tugas-tugasnya dan standar jabatan. Kedua, menilai kinerja berarti membandingkan kinerja aktual atasan dengan standar-standar yang telah ditetapkan, dan ini mencakup beberapa jenis tingkat penilaian. Ketiga, umpan balik berarti kinerja dan kemajuan atasan dibahas dan rencana-rencana dibuat untuk pekermbangan apa saja yang dituntut.

Sedang Suprihanto ( dalam Srimulyo, 1999:33 ) mengatakan bahwa kinerja atau prestasi kerja seorang pegawai pada dasarnya adalah hasil kerja seorang pegawai selama periode tertentu dibandingkan dengan kemungkinan, misalnya standar, target/sasaran atau kinerja yang telah ditentukan terlebih dahulu dan telah disepakati bersama. Menurut Vroom ( dalam As'ad 2001:48 ), tingkat sejauh mana keberhasilan seseorang menyelesaikan pekerjaanya disebut " level of performance ". Biasanya orang yang level of performance-nya tinggi disebut sebagai orang yang produktif, dan sebaliknya orang yang levelnya tidak mencapai standar dikatakan sebagai tidak produktif atau berperfomance rendah. Penilaian kinerja adalah salah satu tugas penting untuk dilakukan oleh seorang manajer atau pimpinan. Walaupun demikian, pelaksanaan kinerja yang obyektif bukanlah tugas yang sederhana. Penilaian harus dihindarkan adanya "like dan dislike" dari penilai, agar obyektifitas peniliaian dapat terjaga. Kegiatan penilaian ini penting, karena dapat digunakan untuk memperbaiki

keputusan-keputusan personalia dan memberikan umpan balik 
kepada para pegawai tentang kinerja mereka.

Menurut Wibowo, (2011:76) ada tiga faktor yang dapat mempengaruhi kinerja seseorang antara lain:

Faktor Individu, yaitu unit terkecil di dalam masyarakat dalam bersosialisasi. atau manusia yang memiliki peran khas/spesifik dalam kepribadiannya.

Faktor Psikologis, yaitu kondisi kejiwaan atau mental seseorang dalam bersosialisasi, Faktor Organisasi

Menurut Suhardjito (2009:3), menyebutkan 6 (enam) faktor utama menentukan kinerja tenaga kerja, yaitu:

Sikap kerja, merupakan kesediaan bekerja secara bergiliran (shif work), dapat menerima tambahan tugas dan bekerja satu tim atau kelompok.

Tingkat keterampilan, merupakan suatu keharusan dalam menunjang kinerja karyawan hal ini biasa ditentukan pendidikan, latihan dan supervisi serta keterampilan dalam teknik industri.

Hubungan antara tenaga kerja dan pimpinan merupakan faktor penting dalam menunjang peningkatan kinerja karena hubungan secara tidak langsung memberikan dampak yang positif terhadap peningkatan kinerja.

Manajemen organisasi merupakan suatu strategi dalam mengelola efesiensi mengenai sumber-sumber dan hukum kerja. Efesiensi tenaga kerja, mengefesiensikan tenaga kerja melalui adanya perencanaan maupun penambahan tugas guna menunjang kinerja.

Kewiraswastaan merupakan penilaian pengambilan resiko, kreativitas dan usaha individu untuk memajukan diri secara sendiri guna menunjang kinerja. Mulyanto (2013:110), menyebutkan indikator utama menentukan atau yang mempengaruhi kinerja tenaga kerja, yaitu:

Sikap kerja, merupakan kesediaan bekerja secara bergiliran, dapat menerima tambahan tugas dan bekerja satu tim atau kelompok.

Tingkat keterampilan, merupakan suatu keharusan dalam menunjang kinerja karyawan hal ini biasa ditentukan pendidikan, latihan dan supervisi serta keterampilan dalam teknik industri.

Hubungan antara tenaga kerja dan pimpinan merupakan faktor penting dalam menunjang peningkatan kinerja karena hubungan secara tidak langsung memberikan dampak yang positif terhadap peningkatan kinerja.

Sedangkan menurut Tiffin dan Me. Cormick (dalam Srimulyo, 1999:40) ada dua variabel atau faktor yang dapat mempengaruhi kinerja, yaitu :

Variabel Individual, meliputi : Sikap, karakreristik, sifat-sifat fisik, minat dan motivasi, pengalaman, umur, jenis kelamin, pendidikan serta faktor invidual lainnya.

Variabel situasional :

Faktor fisik dan pekerjaan, terdiri dari ; metode kerja, kondisi dan desain perlengkapan kerja, penataan ruang dan lingkungan fisik (penyinaran, temperature dan fentilasi )

Faktor Sosial dan organisasi, meliputi : peraturan-peraturan organisasi, sifat organisasi, jenis latihan dan pengawasan, sistem upah dan lingkungan sosial.

Sutemeister (dalam Srimulyo, 1999:40-41) mengemukakan pendapatnya, bahwa kinerja dipengaruhi oleh dua faktor, yaitu : Faktor Kemampuan

Pengetahuan : pendidikan, pengalaman, latihan dan minat

Keterampilan : kecakapan dan kepribadian Faktor motivasi

Kondisi sosial : organisasi formal dan informal, kepemimpinan dan

Serikat kerja kebutuhan individu : fisiologi, social dan egoistic

Kondisi fisik : lingkungan kerja

\subsection{Penelitian Terdahulu}

1. Muhammad Firdaus, 2016, Analisis Faktor-faktor Yang Mempengaruhi Kinerja Pegawai Pada Puskesmas Pisangan Jakarta. Analisis menggunakan kuantitatip dengan alat uji regresi berganda dan populasi dan sampel yang ditelliti sebanyak 65 orang. Hasil penelitian yang didapat ketiga variable dalam penelitian ini, yaitu faktor psikologi, faktor organisasi dan faktor individu dan hasilnya ketiga variabel 
berpengaruh signifikan terhadap kinerja pegawai baik secara simultan maupun parsialdan variabel yang dominan adalah faktor psikologi. Persamaan dalam penelitian penulis adalah sama-sama mengangkat masalah manajemen sumber daya manusia khususnya masalah faktor kinerja dan teknik analisis data yaitu Analisis Regresi Linier Berganda. Sedangkan perbedaannya adalah objek penelitian, periode penelitian, dan variabel yang digunakan dan sebagian variabel yang diteliti.

2. Lukman Hakim, 2012, Analisis Faktor Kinerja Pegawai terhadap Kinerja Pegawai pada kantor Samsat Kota Banjarmasin. Analisis menggunakan kuantitatip dengan alat uji regresi berganda dan populasi dan sampel yang ditelliti sebanyak 70 orang. Kesimpulan dalam penelitian ini adalah faktor kinerja terdiri dari faktor psikologi, faktor organisasi dan faktor individu dan pemenuhan kebutuhan berpengaruh positif terhadap kinerja pegawai baik secara parsial maupun simultan. Persamaan penelitian terdahulu dengan penelitian yang dilakukan penulis adalah sama-sama mengangkat masalah manajemen sumber daya manusia serta analisis yang digunakan regresi berganda, sedangkan perbedaannya adalah objek penelitian, periode penelitian dan variabel digunakan serta sebahagian variabel yang diteliti.

3. Sulastri, 2013, Analisis Faktor Kinerja Pegawai Pada Dinas Kehutanan Propinsi Kalimantan Selatan. Analisis menggunakan kuantitatip dengan alat uji regresi berganda dan populasi dan sampel yang ditelliti sebanyak 83 orang. Kesimpulan dalam penelitian ini adalah kompensasi, tekanan pekerjaan, individu, organisasi, lingkungan kerja dan psikologi berpengaruh positif terhadap kinerja pegawai baik secara parsial maupun secara simultan. Persamaan penelitian terdahulu dengan penelitian yang dilakukan penulis adalah sama-sama mengangkat masalah manajemen sumber daya manusia dan analisis yang digunakan, sedangkan perbedaannya adalah objek penelitian, periode penelitian dan variabel digunakan.

Erwinda, 2010, Pengaruh Pengaruh Faktor Kinerja Melalui Faktor Pengembangan Karier, Tekanan Pekerjaan, Pimpinan, Individu dan Kompensasi terhadap Kinerja Pegawai pada Dinas Koperasi dan UKM Kabupaten Balangan. Analisis menggunakan kuantitatip dengan alat uji regresi berganda dan populasi dan sampel yang ditelliti sebanyak 65 orang kesimpulan dalam penelitian ini adalah pengembangan karier, tekanan pekerjaan, pimpinan, individu dan kompensasi berpengaruh positif baik secara parsial maupun secara simultan terhadap kinerja pegawai. Persamaan penelitian terdahulu dengan penelitian yang dilakukan penulis adalah sama-sama mengangkat masalah manajemen sumber daya manusia serta sebagian variabel yang ditelitia sedangkan perbedaannya adalah objek penelitian, periode penelitian, variabel digunakan dan sampel yang digunakan.

\section{KERANGKA KONSEPTUAL DAN HIPOTESIS}

\subsection{KerangkaKonseptual}

Kerangka konseptual merupakan susunan atau rangkaian dari variable bebas dan terikat dalam menjelaskan mana yang termasuk dependent maupun independent, di mana label $\mathrm{X}$ untuk variable bebas (independent) dan label Y untuk variable terikat (dependent). Berdasarkan uraian tersebut di atas baik dari rumusan masalah, tujuan penelitian yang telah dikemukakan sebelumnya dan pendekatan teoritis, maka model kerangka konseptual tersebut dapat jelaskan dan digambarkan sebagai berikut: 


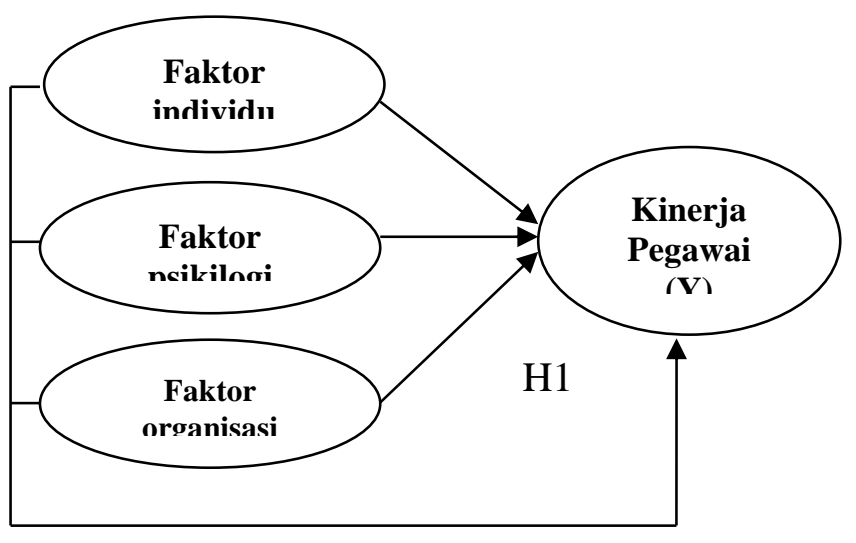

Gambar 3.1 : Kerangka Konseptual

Sumber : Data DiolahPenulis

\subsection{Hipotesis Penelitian}

Adapun hipotesis dalam penelitian ini dapat dijelaskan sebagai berikut:

H1 Faktor individu, faktor psikologi dan faktor organisasi berpengaruh signifikan secara parsial terhadap kinerja pegawai Satgas Kebersihan di Dinas Lingkungan Hidup Kabupaten Balangan.

$\mathrm{H} 2$ Faktor individu, faktor psikologi dan faktor organisasi berpengaruh signifikan secara simultan terhadap kinerja pegawai Satgas Kebersihan di Dinas Lingkungan Hidup Kabupaten Balangan

H3 Faktor individu berpengaruh dominan terhadap kinerja pegawai Satgas Kebersihan di Dinas Lingkungan Hidup Kabupaten Balangan.

\section{METODE PENELITIAN}

\subsection{Rancangan Penelitian}

Rancangan penelitian menjelaskan akan konsep dasar dalam penelitian ini, dimana rancangan penelitian ini merupakan suatu penelitian yang berbentuk inferensial dengan menggunakan pendekatan positifistik, yaitu pendekatan yang menggunakan pola piker edukatif dengan melihat gejala-gejala umum kemudian dilanjutkan ke hal-hal yang lebih khusus, di mana data yang dikumpulkan dari hasil kuosioner dari para pegawai yang menggambarkan dan menjelaskan tentang faktor kinerja melalui faktor individu, faktor psikologi dan faktor organisasi berpengaruh signifikan secara parsial terhadap kinerja pegawai Satgas
Kebersihan di Dinas Lingkungan Hidup Kabupaten Balangan.

\subsection{Definisi Operasional Variabel}

Adapun variabel-variabel yang akan dikumpulkan dalam penelitian ini adalah:

Faktor individu (X1) adalah unit terkecil di dalam masyarakat dalam bersosialisasi. atau manusia yang memiliki peran khas/spesifik dalam kepribadiannya.

Faktor psikologi (X2) adalah kondisi kejiwaan atau mental seseorang dalam bersosialisasi.

Faktor organisasi (X3) adalah hubungan yang dilalui atau perkumpulan manusia untuk mencapai tujuan bersama.

Kinerja pegawai, dinyatakan dengan (Y), merupakan hasil kerja yang dihasilkan oleh pegawai atau perilaku nyata yang ditampilkan sesuai peranannya dalam organisasi.

\subsection{Jenis dan Sumber Data Penelitian}

\subsubsection{Jenis Data}

Adapun jenis data dalam penelitian ini yang penulis ambil, yaitu sebagai berikut:

Data Kualitatif, yaitu berupa data atau informasi yang tidak berbentuk angka. Penulis mengangkat data tersebut dari hasil wawancara dengan pihak Dinas Lingkungan Hidup Kabupaten Balangan, yakni berupa data tentang sejarah instansi, struktur organisasi, bidang operasional yang dilakukan atau proses kerja.

Data Kuantitatif yaitu data yang berbentuk angka, yang diangkat dari dokumen instansi dalam hal ini tentang data jumlah pegawai, data tabulasi dan data lain yang berhubungan dengan penelitian.

\subsubsection{Sumber Data}

Data Primer merupakan data penelitian yang diperoleh secara langsung dari sumber asli secara khusus di kumpulkan oleh peneliti untuk menjawab pertanyaan yang diajukan melalui daftar pertanyaan.

Data Sekunder merupakan data penelitian yang diperoleh secara tidak langsung melalui media perantara seperti informasi dan publikasi atau laporan historis yang telah tersusun dalam dokumen/arsip.

\subsection{Populasi dan Sampel}

\subsubsection{Populasi Penelitian}

Dalam penelitian ini juga akan ditentukan besar populasi yang digunakan. Di mana 
menurut Arikunto, (1990 : 102 ) populasi adalah keseluruhan subyek penelitian. Populasi dari penelitian ini adalah semua satgas kebersihan di Dinas Lingkungan Hidup Kabupaten Balangan yang berjumlah sebanyak 145 Orang.

\subsubsection{Sampel Penelitian}

Menurut Arikunto, ( 1992 : 107 ) apabila populasi kurang dari 100 orang, maka semua akan menajdi sampel, jika populasi lebih dari 100, maka akan diambil 5\%-10\% atau 20\%-25\% dari jumlah populasi, maka berdasarkan pendapat ini semua populasi di dalam penelitian ini dijadikan sampel penelitian dengan jumlah 31 responden atau sebanyak $22 \%$ dari jumlah populasi dan metode yang digunakan dalam pengambilan sampel penelitian ini menggunakan metode sensus.

\subsection{Teknik Pengumpulan Data}

1. Observasi, yaitu pengumpulan data melalui pengamatan secara umum pada Dinas Lingkungan Hidup Kabupaten Balangan sebagai dasar untuk mengidentifikasi permasalahan yang akan dibahas.

2. Wawancara, yaitu mengumpulkan data dengan mengadakan Tanya jawab secara lisan dengan pihak Dinas Lingkungan Hidup Kabupaten Balangan pada waktu yang telah ditentukan.

3. Dokumentasi, yaitu teknik pengumpulan data melalui pencatatan dan pengumpuan data instansi yang berkaitan dengan permasalahan.

4. Studi kepustakaan, yaitu pengumpulan data melalui atau mempelajari berbagai literatur dan bahan bacaan lainnya yang berhubungan dengan permasalahan yang akan dibahas.

5. Kuisioner, yaitu pengumpul data dengan cara membagikan daftar pertanyaan secara tertulis kepada pegawai pada Dinas Lingkungan Hidup Kabupaten Balangan untuk memperoleh data primer yang diperlukan dalam penyusunan tesis ini.

\subsection{Teknik Analisis Data}

Penelitian ini berdasarkan jenis data, merupakan penelitian asosiatif dengan paradigma kuantitatif. Penelitian ini bertujuan untuk mengetahui hubungan antara dua variable atau lebih dengan menggunakan data numerik. Bentuk hubungan variabel pada penelitian ini berupa kausal (sebab-akibat), yang ditujukan dengan pengaruh variabel independen terhadap variabel dependen. Penelitian ini bertujuan untuk memperoleh kejelasan hubungan antar variabel dengan menggunakan perhitungan statistik dengan program SPSS 17.

\subsubsection{Uji Instrumen}

\section{Uji Validitas}

Pengambilan keputusan untuk valid instrument pertanyaan adalah Jika rhitung positif dan rhitung $>$ rtabel maka instrument valid. Jika rtabel negative dan rhitung < rtabel maka instrument tidak valid.

\section{Uji Reliabilitas}

Uji signifikasi dilakukan pada taraf signifikasi 0,05 , artinya instrument dapat dikatakan reliabel bila nilai alpha lebih besar dari rkritis product moment.

\section{Uji Asumsi Klasik}

\section{a. Uji Multikolinearitas}

Deteksi terhadap gangguan multikolinearitas dapat dilihat dari nilai VIF (variance inflation factor) dan nilai tolerance (Pratsito, 2004, 156-161). Tolerance mengukur variabilitas variabel bebas yang terpilih yang tidak dapat dijelaskan oleh variabel bebas lainnya. Jadi nilai tolerance yang rendah sama dengan nilai VIF tinggi (karena VIF $=1 /$ tolerance) dan menunjukkan adanya koloniritas yang tinggi.Multikolineritas dapat diketahui dengan memeriksa nilai VIF (variance inflation factor) yang merupakan unsure diagonal invers matrik korelasi sederhana antara perubah bebas. Apabila beberapa nilai VIF lebih dari $10 \mathrm{mk}$ multikolinearitas adalah sebuah masalah. Solimun,(2004:35).

\section{b. Uji Heteroskedastisitas}

Jika diagram pencar yang membentuk polapola tertentu yang teratur maka regresi mengalami gangguan heteroskedastisitas. Jika diagram pencar tidak membentuk pola atau acak maka regresi tidak mengalami gangguan heteroskedastisitas.

\section{c. Uji Normalitas (kenormalan)}

Menurut Solimun (2004,46) dapat dilakukan dengan cara membuat plot antara skor normal dengan data observasi dan 
melihat penyebaran data (titik) pada sumbu diagonal dari grafik. Bilamana hasil plot menunjukkan pola garis lurus mendekati $45^{\circ}$ berarti asumsi normalitas terpenuhi.

\section{d. Uji Linearitas}

Uji linearitas bertujuan untuk mengetahui apakah dua variable mempunyai hubungan yang linear atau tidak secara signifikan. Uji ini biasanya d igunakan sebagai prasyarat dalam analisis korelasi atau regresi linear. Pengujian test for linearity dengan taraf signifikasi 0,05. dua variable di katakana mempunyai hubungan yang linear bila signifikasi kurang dari 0,05 (Priyatno, 2009:36)

\section{e. Uji Autokorelasi}

Untuk mendeteksi ada/tidak adanya autokorelasi pada penelitian ini menggunakan uji Durbin-Watson (DW test) yaitu nilai DW $<1,10$; ada autokorelasi, nilai DW anatar 1,10 s.d 1,54 ; tanpa kesimpulan, nilai DW antara 1,55 s.d 2,45 ; tidak ada autokorelasi, nilai DW antara 2,46 s.d 2,91; tanpa kesimpulan dan nilai DW > 2,91; ada autokorelasi. (Ghozali, 2009, 68).

\section{Analisa Regresi Linier Berganda}

Analisis data dilakukan berdasarkan data primer yang diperoleh langsung dari penyebaran kuisioner kepada pegawai yang selanjutnya akan dianalisis dengan paket program SPSS (statistic produk service solution) for windows melalui bantuan program computer. Untuk menguji hipotesa dalam penelitian ini menggunakan analisis regresi linier berganda. Adapun rumus dari regresi linier berganda adalah :

$\mathbf{Y}=\mathbf{a}+\boldsymbol{\beta 1 . X 1}+\boldsymbol{\beta 2 . X 2}+\boldsymbol{\beta 3} . \mathrm{X} 3+\varepsilon$

Uji Hipotesis

a.Uji t (parsial)

untuk menentukan HA diterima atau HA ditolak maka digunakan perbandingan Jika thitung < ttabel berarti HA ditolak.Jika thitung $>$ ttabel berarti HA diterima.

\section{b.Uji F (simultan)}

Untuk menentukan HA diterima atau HA ditolak maka digunakan perbandingan Jika Fhitung < Ftabel berarti HA ditolak. Jika Fhitung $>$ Ftabel berarti HA diterima.

\section{Uji Dominan}

Untuk mengkaji variabel yang dominan digunakan indikator koefisien beta standardized dari variabel-variabel dari model regresi. Koefisien beta standardized diperoleh dari hasil perkalian antara koefisien parsial korelasi (SDx $1 / \mathrm{Sdy}$ ) dan koefisien variabelnya (bi). Selain itu Pratisto (2004:160) keeratan hubungan variabel dapat diambil dari thitung dengan standar $\mathrm{t}$ tabel.

\section{BAB V \\ ANALISIS HASIL PENELITIAN DAN PEMBAHASAN}

\subsection{Analisis Hasil Penelitian}

\subsubsection{Pengujian Instrumen Penelitian}

\section{Uji Validitas}

Adapun hasil uji validitas dalam penelitian ini adalah sebagai berikut:

Tabel 5.9

Uji Validitas Variabel Individu (X1)

\begin{tabular}{|l|l|l|}
\hline Variable & $\begin{array}{l}\text { rhitung } \\
\text { (lihat } \\
\text { lampiran 3) }\end{array}$ & $\begin{array}{l}\text { rtabel } \\
\text { (lihat } \\
\text { lampiran 6) }\end{array}$ \\
\hline $\mathrm{X} 1.1$ & $0,466(* *)$ & 0,355 \\
$\mathrm{X} 1.2$ & $0,599(* *)$ & 0,355 \\
$\mathrm{X} 1.3$ & $0,479(* *)$ & 0,355 \\
$\mathrm{X} 1.4$ & $0,495(* *)$ & 0,355 \\
X1.5 & $0,427(* *)$ & 0,355 \\
\hline
\end{tabular}

Sumber : Data spss diolah

Hasil uji validitas terhadap instrumen pertanyaan faktor individu (X1) yang diajukan dapat disimpulkan bahwa semua instrumen pertanyaan tersebut valid ini terbukti dengan membandingkan (rhitung) dengan rtabel pada $\alpha 0,05$ yang menurut Sulistyo, (2002:44) diambil keputusan jika nilai rhitung positip dan rhitung > rtabel dengan signifikasi 5\% uji 2 sisi, maka instrumen pertanyaan tersebut valid .

Tabel 5.10

Uji Validitas Variabel Psikologi (X2)

\begin{tabular}{|l|l|l|}
\hline Variable & $\begin{array}{l}\text { rhitung } \\
\text { (lihat lampiran } \\
\text { 3) }\end{array}$ & $\begin{array}{l}\text { rtabel } \\
\text { (lihat } \\
\text { lampiran 6) }\end{array}$ \\
\hline X2.1 & $0,460(* *)$ & 0,355 \\
X2.2 & $0,691(* *)$ & 0,355 \\
X2.3 & $0,539(* *)$ & 0,355 \\
X2.4 & $0,433(* *)$ & 0,355 \\
X2.5 & $0,451(* *)$ & 0,355 \\
X2.6 & $0,473(* *)$ & 0,355 \\
\hline
\end{tabular}

Sumber : Data Spss diolah

Hasil uji validitas terhadap instrumen pertanyaan faktor psikologi (X2) yang diajukan dapat disimpulkan bahwa semua instrumen pertanyaan tersebut valid ini 
terbukti dengan membandingkan (rhitung) dengan rtabel pada $\alpha 0,05$ yang mana menurut Sulistyo, (2002:44) diambil keputusan jika nilai rhitung positip dan rhitung > rtabel dengan signifikasi $5 \%$ uji 2 sisi, maka instrumen pertanyaan valid.

Tabel 5.11

Uji Validitas Variabel Organisasi (X3)

\begin{tabular}{|c|c|c|}
\hline Variable & $\begin{array}{c}\text { rhitung } \\
\text { (lihat } \\
\text { lampiran 3) }\end{array}$ & $\begin{array}{c}\text { rtabel } \\
\text { (lihat } \\
\text { lampiran 6) }\end{array}$ \\
\hline X3.1 & $0,567(* *)$ & 0,355 \\
X3.2 & $0,490(* *)$ & 0,355 \\
X3.3 & $0,460(* *)$ & 0,355 \\
X3.4 & $0,455(* *)$ & 0,355 \\
\hline
\end{tabular}

Sumber : Data spss diolah

Hasil uji validitas terhadap instrumen pertanyaan faktor organisasi (X3) yang diajukan dapat disimpulkan bahwa semua instrumen pertanyaan tersebut valid ini terbukti dengan membandingkan (rhitung) dengan rtabel pada $\alpha 0,05$ yang mana menurut Sulistyo, (2002:44) diambil keputusan jika nilai rhitung positip dan rhitung > rtabel dengan signifikasi $5 \%$ uji 2 sisi, maka instrumen pertanyaan tersebut valid.

Table 5.12

Uji Validitas Variabel Kinerja (Y)

\begin{tabular}{|c|c|c|}
\hline Variable & $\begin{array}{c}\text { rhitung } \\
\text { (lihat lampiran } \\
\text { 3) }\end{array}$ & $\begin{array}{c}\text { Rtabel } \\
\text { (lihat lamp } \\
\text { 6) }\end{array}$ \\
\hline Y1.1 & $0,667(* *)$ & 0,355 \\
Y1.2 & $0,490(* *)$ & 0,355 \\
Y1.3 & $0,414(* *)$ & 0,355 \\
Y1.4 & $0,426(* *)$ & 0,355 \\
Y1.5 & $0,422(* *)$ & 0,355 \\
\hline
\end{tabular}

Sumber : Data spss diolah

Hasil uji validitas terhadap instrumen pertanyaan kinerja pegawai satgas kebersihan (Y) yang diajukan dapat disimpulkan bahwa semua instrumen pertanyaan tersebut valid ini terbukti dengan membandingkan (rhitung) dengan rtabel pada $\alpha 0,05$ yang mana menurut Sulistyo, (2002:44) diambil keputusan jika nilai rhitung positip dan rhitung > rtabel dengan signifikasi 5\% uji 2 sisi, maka instrumen pertanyaan tersebut valid.
Berikut rekapitulasi dari hasil uji reliabilitas instrument, sebagai berikut;

Tabel 5.13

Hasil Uji Reliabilitas

\begin{tabular}{|l|l|l|}
\hline Variable & $\begin{array}{l}\text { Cronbach } \\
\text { Alpha }\end{array}$ & $\begin{array}{l}\text { Nilai } \\
\text { Baku }\end{array}$ \\
\hline Individu (X1) & 0,671 & 0,60 \\
Psikologi (X2) & 0,687 & 0,60 \\
Organisasi & 0,680 & 0,60 \\
(X3) & 0,649 & 0,60 \\
Kinerja (Y) & & \\
\hline
\end{tabular}

Sumber: Output Spss Diolah (lihat lampiran 4)

Melihat hasil uji tersebut nilai Cronbach $\mathrm{A}_{\text {lpha }}$ lebih besar dari nilai baku, sehigga dengan demikian dapat dikatakan data hasil uji reliabilitas masing-masing variabel datanya reliabel karena konstruk atau variabel dikatakan reliabel jika memberikan nilai Cronbach $A_{1 p h a}>0,60$. (Ghozali, 2006, 41-42).

\subsubsection{Uji Asumsi Klasik}

\section{Uji Multikolinieritas}

Dari hasil uji regresi maka dapat diketahui hasil uji mulkolinieritas. Berikut hasil uji multikolinieritas dalam penelitian ini, yaitu:

Tabel 5.14

Hasil Uji Multikolinieritas

\begin{tabular}{|l|l|l|}
\hline \multirow{2}{*}{ Variabel } & \multicolumn{2}{|l|}{$\begin{array}{l}\text { Collinierarity } \\
\text { Statistic's }\end{array}$} \\
\cline { 2 - 3 } & Tolerance & VIF \\
\hline Individu (X1) & 0,980 & 1,096 \\
\hline Psikologi (X2) & 0,990 & 1,224 \\
\hline Organisasi (X3) & 0,987 & 1,119 \\
\hline
\end{tabular}

Sumber: Output Spss Diolah (lihat lampiran 5)

Melihat data pada tabel tersebut dapat disimpulkan hasil uji multikolinieritas tidak ada gejala multikolinieritas antar variabel bebas dalam model regresi karena nilai tolerance mendekati 1 dan nilai variance inflation factor (VIF) menunjukkan tidak ada satu pun variabel bebas yang memiliki nilai VIF lebih dari 10.

\section{Uji Heteroskedastisitas}

Berikut hasil uji heteroskedastisitas dapat digambarkan sebagai berikut:

\section{Uji Reliabilitas}


(lihat lampiran 5) nilai ni masuk dalam nilai DW antara 1,55 s.d 2,45 (mendekati 2),

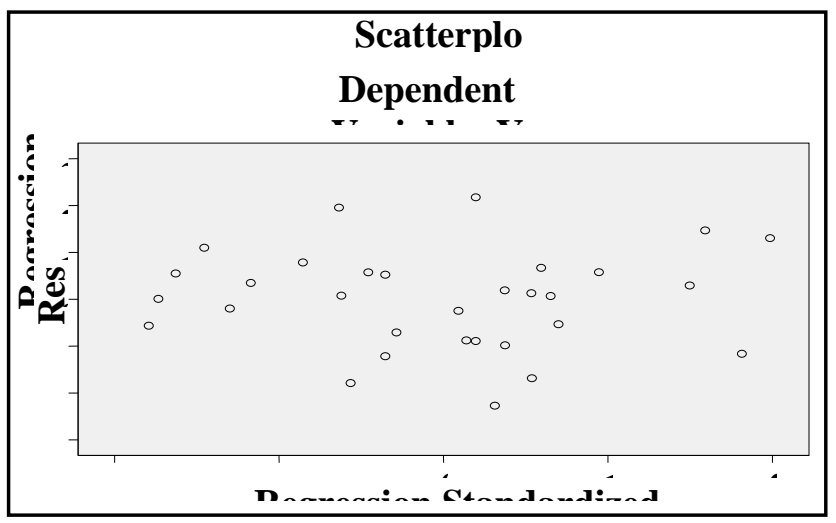
dapat disimpulkan bahwa tidak terdapat otokorelasi antara variabel bebas dengan variabel terikat.

\section{Uji Linearitas}

Untuk menguji garis regresi variabel bebas $\mathrm{X}$ terhadap variabel terikat $\mathrm{Y}$ berdasarkan uji linearitas (lihat lampiran 5). Dari output regresi tersebut diketahui bahwa nilai signifikasi pada linearity sebesar 0,003, karena signifikasi kurang dari 0,05, maka dapat disimpulkan bahwa

Gambar 5.2 : Scatterplot

Sumber : lampiran 5

Grafik scatterplots di atas ini terlihat titiktitik menyebar secara acak serta tersebar baik di atas maupun di bawah angka 0 pada sumbu Y. Hal ini dapat disimpulkan bahwa tidak terjadi heteroskedastisitas pada model regresi, sehingga model regresi layak dipakai untuk memprediksi variabel terikat berdasarkan pengaruh variabel bebas.

\section{Uji Normalitas}

Adapun hasil dari uji normalitas dalam penelitian ini, yaitu:

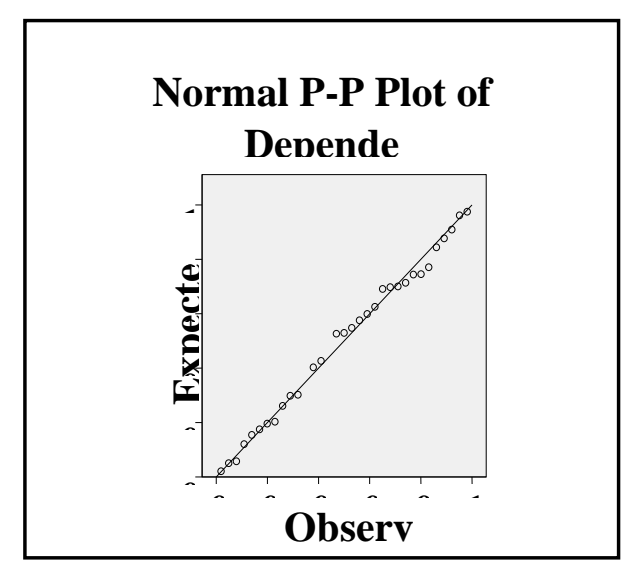

Gambar 5.3 Diagram Normal P-P Plot

Sumber: lampiran 5

Hasil uji normalitas menunjukkan bahwa grafik terlihat titik-titik menyebar disekitar garis diagonal, serta penyebarannya mengikuti arah garis diagonal, ini menunjukkan bahwa model regresi layak dipakai untuk memprediksi variabel dependen berdasarkan masukan dari variabel independen, karena memenuhi uji asumsi normalitas.

\section{Uji Autokorelasi}

Hasil uji dalam penelitian ini diketahui nilai uji Durbin Watson (DW) sebesar 2,391 antara variabel bebas $\mathrm{X}$ dengan variabel terikat $\mathrm{Y}$ terdapat hubungan yang linear.

\subsubsection{Analisis Regresi Berganda}

Untuk menguji hal tersebut, perlu dilakukan uji hipotesis dengan menggunakan uji regresi berganda melalui program spss, berikut ini rekapitulasi hasil regresi berganda tersebut, adalah :

Tabel 5.15

\section{Analisis Regresi Berganda Coefficients(a)}

\begin{tabular}{|c|c|c|c|c|c|c|c|}
\hline & \multicolumn{2}{|c|}{$\begin{array}{l}\text { Unstandardi } \\
\text { zed } \\
\text { Coefficients }\end{array}$} & \multirow{2}{*}{$\begin{array}{l}\text { Standardi } \\
\text { zed } \\
\text { Coefficie } \\
\text { nts } \\
\text { Beta } \\
\end{array}$} & \multirow[b]{2}{*}{$\mathrm{t}$} & \multirow[b]{2}{*}{ Sig } & \multicolumn{2}{|c|}{$\begin{array}{l}\text { Collinearity } \\
\text { Statistics }\end{array}$} \\
\hline & B & $\begin{array}{l}\text { Std. } \\
\text { Err } \\
\text { or }\end{array}$ & & & & $\begin{array}{l}\text { Tolera } \\
\text { nce }\end{array}$ & VIF \\
\hline (Consta & 10,1 & 4,3 & & 2,3 &, 00 & & \\
\hline & 64 & 17 & & 54 & 2 & & \\
\hline X1 & ,654 & $\begin{array}{l}, 13 \\
4\end{array}$ & ,616 & $\begin{array}{l}4,8 \\
80\end{array}$ & $\begin{array}{l}, 00 \\
2\end{array}$ & ,980 & $\begin{array}{l}1,0 \\
96\end{array}$ \\
\hline $\mathrm{X} 2$ & 846 &, 11 & 846 & 7,6 & ,00 & 990 & 1,2 \\
\hline X3 & 778 &, 12 & 730 & 6,4 & 00 & 087 & 1,1 \\
\hline &, $1 / 8$ & 0 & , & 83 & 1 & 198, & 19 \\
\hline
\end{tabular}

a Dependent Variable: Y

Sumber: Output Spss Diolah (lihat lampiran 5)

Hasil perhitungan dari pengaruh antar variabel individu (X1), psikologi (X2) dan organisasi (X3) terhadap kinerja pegawai satgas kebersihan (Y), maka dapat disusun persamaan struktural untuk model regresi sebagai berikut:

$Y=10,164+0,654 X 1+0,846 \times 2+0,778 X 3$ $+\mathrm{e}$

\section{Uji Hipotesis}

\section{a. Uji Hipotesis Parsial}

Faktor individu, faktor psikologi dan faktor organisasi berpengaruh signifikan secara parsial terhadap kinerja pegawai Satgas 
Kebersihan di Dinas Lingkungan Hidup Kabupaten Balangan

Untuk mengetahui akan pengujian hipotesis secara parsial terlebih dahulu harus diketahui akan ttabel dengan cara mendapatkan ttabel digunakan tabel distribusi $\mathrm{t}$ untuk tingkat signifikasi 5\% dengan Degrees of Freedom (df) $=\mathrm{n}-\mathrm{k}$ maka di dapat df adalah $(31-4)=27$ dengan demikian ttabel adalah sebesar 1,703.

Berikut dapat dikemukakan hasil uji hipotesis secara parsial dalam penelitian ini, yaitu:

Faktor individu berpengaruh signifikan terhadap kinerja pegawai satgas kebersihan Hasil uji regresi dan penetapan data pada tabel baku ttabel, maka dapat dilihat dari perbandingan nilai thitung lebih besar dari $\mathrm{t}_{\text {tabel }}$ yaitu : $\left(\mathrm{t}_{\text {hitung }}=4,880>\mathrm{t}_{\text {tabel }}=1,703\right)$ atau signifikansi $p<0,05$ yaitu $0,002<$ 0,05, berdasarkan hasil tersebut maka hipotesis pertama yang menyebutkan secara parsial antara variabel individu berpengaruh signifikan terhadap kinerja pegawai satgas kebersihan pada Dinas Lingkungan Hidup Kabupaten Balangan, diterima.

Besarnya pengaruh variabel individu (X1) terhadap kinerja pegawai satgas kebersihan (Y) dapat diketahui dari Standardized Coefficients Beta 0,616 yang berarti faktor individu ini mempengaruhi kinerja pegawai satgas kebersihan terhadap sebesar $61,6 \%$.

b. Faktor psikologi berpengaruh signifikan terhadap kinerja pegawai pegawai satgas kebersihan. Hasil uji regresi dan penetapan data pada tabel baku ttabel, maka dapat dilihat dari perbandingan nilai $t_{\text {hitung }}$ lebih besar dari tabel yaitu : $\left(\mathrm{t}_{\text {hitung }}=7,621>\mathrm{t}_{\text {tabel }}=1,703\right)$ atau signifikansi $p<0,05$ yaitu $0,002<0,05$, berdasarkan hasil tersebut maka hipotesis pertama yang menyebutkan secara parsial antara variabel psikologi berpengaruh signifikan terhadap kinerja pegawai satgas kebersihan pada Dinas Lingkungan Hidup Kabupaten Balangan, diterima. Besarnya pengaruh variabel psikologi (X2) terhadap kinerja pegawai satgas kebersihan (Y) dapat diketahui dari Standardized Coefficients Beta 0,846 yang berarti faktor psikologi ini memberikan pengaruhi kepada kinerja pegawai satgas kebersihan terhadap sebesar $84,6 \%$

c. Faktor organisasi berpengaruh signifikan terhadap kinerja pegawai satgas kebersihan

Hasil uji regresi dan penetapan data pada tabel baku ttabel, maka dapat dilihat dari perbandingan nilai $t_{\text {hitung lebih besar dari }}$ $\mathrm{t}_{\text {tabel }}$ yaitu : $\left(\mathrm{t}_{\text {hitung }}=6,483>\mathrm{t}_{\text {tabel }}=\right.$ 1,703) atau signifikansi $p<0,05$ yaitu $0,001<0,05$, berdasarkan hasil tersebut maka hipotesis pertama yang menyebutkan secara parsial antara variabel organisasi berpengaruh signifikan terhadap kinerja pegawai satgas kebersihan pada Dinas Lingkungan Hidup Kabupaten Balangan, diterima. Besarnya pengaruh variabel organisasi (X3) terhadap kinerja pegawai satgas kebersihan (Y) dapat diketahui dari Standardized Coefficients Beta 0,730 yang berarti faktor organisasi ini memberikan pengaruh kinerja pegawai satgas kebersihan terhadap sebesar $73 \%$

\section{Uji Hipotesis Simultan}

Faktor individu, faktor psikologi dan faktor organisasi berpengaruh signifikan secara simultan terhadap kinerja pegawai Satgas Kebersihan di Dinas Lingkungan Hidup Kabupaten Balangan

Selanjutnya untuk menguji pengaruh secara simultan data yang digunakan adalah tabel Anova berikut ini:

Tabel 5.16

$\operatorname{ANOVA}(b)$

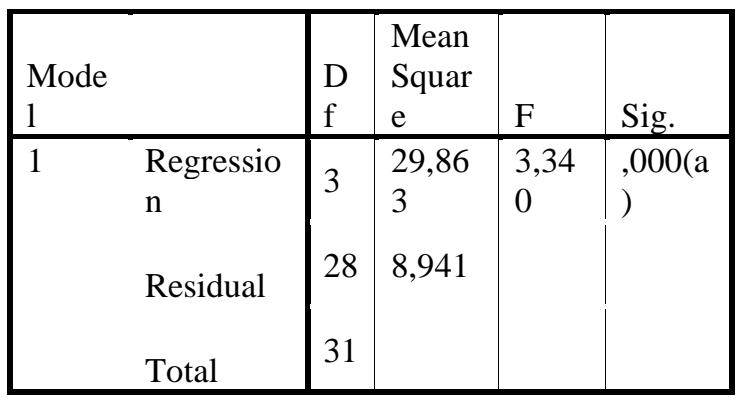

a Predictors: (Constant), X3, X1, X2

b Dependent Variable: Y

Sumber : data primer diola (lihat lampiran 5)

Hasil regresi memperlihatkan bahwa $F_{\text {hitung }}$ adalah 3,340 sedangkan untuk mengetahui 
akan nilai $\mathrm{F}_{\text {table }}$ dengan cara menentukan tingkat signifikan $5 \%$ kemudian menentukan derajat bebas bagi pembilang (numerator) dengan dasar (k-1) sehingga didapat $(4-1)=3$, sedangkan derajat kebebasan bagi pembagi (denumerator) adalah $(n-k)$ sehingga didapat (31-4) $=27$. Dengan demikian didapat $F_{\text {tabel }}$ dengan numerator $=3$ dan denumurator 27 sebesar 2,960.

Berdasarkan data tersebut, maka diketahui bahwa pengujian hipotesis kedua menunjukkan bahwa faktor individu (X1), psikologi (X2) dan organisasi (X3) secara simultan berpengaruh signifikan terhadap kinerja pegawai satgas kebersihan (Y) pada Dinas Lingkungan Hidup Kabupaten Balangan, hal ini berdasarkan dari nilai $F_{\text {hitung }}$ lebih besar dari $F_{\text {tabel }}$ yakni : $\left(F_{\text {hitung }}=\right.$ $\left.3,340>\mathrm{F}_{\text {tabel }}=2,960\right)$ atau signifikansi $p<$ 0,05 yaitu $0,000<0,05$. Tingkat kepercayaan yang diambil dalam penelitian ini sebesar 95\% dengan tingkat kesalahan $(\alpha)$ sebesar 5\%.

Dengan demikian hipotesis kedua $\left(\mathrm{H}_{2}\right)$ yang menyatakan bahwa secara simultan bahwa faktor individu (X1), psikologi (X2) dan organisasi (X3) secara simultan berpengaruh signifikan terhadap kinerja pegawai satgas kebersihan (Y) pada Dinas Lingkungan Hidup Kabupaten Balangan, maka hipotesis kedua $\left(\mathrm{H}_{2}\right)$, diterima.

Kemudian untuk melihat seberapa besar pengaruh dari variabel faktor individu (X1), psikologi (X2) dan organisasi (X3) terhadap kinerja pegawai satgas kebersihan (Y) pada Dinas Lingkungan Hidup Kabupaten Balangan dapat dilihat dengan uji determinan, untuk itu data yang diperlukan adalah :

Tabel 5.17

Model Summary(b)

\begin{tabular}{|l|l|l|l|l|}
\hline & & & & \\
Model & $\mathrm{R}$ & $\begin{array}{l}\text { R } \\
\text { Square }\end{array}$ & $\begin{array}{l}\text { Adjusted } \\
\text { R Square }\end{array}$ & $\begin{array}{l}\text { Durbin- } \\
\text { Watson }\end{array}$ \\
\hline 1 &, $826($ a) & ,781 &, 767 & 2,391 \\
\hline
\end{tabular}

a Predictors: (Constant), X3, X1, X2

b Dependent Variable: Y

Sumber : data primer diola (lihat lampiran 5)
Uji determinan adalah untuk regresi dengan lebih dari dua variabel bebas digunakan $R$ Square sebagai keofesien diterminan dari data tersebut terlihat $R$ Square sebesar 0,781 disini berarti $78,1 \%$ variasi kinerja pegawai satgas kebersihan (Y) bisa dijelaskan oleh variabel seperti faktor individu (X1), faktor psikologi (X2) dan organisasi (X3), sedangkan sisanya dari $(100 \%-78,1 \%)=21,9 \%$ dijelaskan oleh variabel lain yang tidak dianalisis pada penelitian ini seperti faktor kompensasi, disiplin dan lain-lain.

\section{Uji Hipotesis Dominan}

Faktor individu berpengaruh dominan terhadap kinerja pegawai Satgas Kebersihan di Dinas Lingkungan Hidup Kabupaten Balangan.

Berdasarkan hasil uji regresi diketahui masing-masing nilai Standardized Coefficients Beta untuk variabel faktor inidvidu (X1) sebesar 0,614, untuk variabel psikologi (X2) sebesar 0,846, dan variabel organisasi sebesar 0,730 .

Kemudian bila dilihat dari kepotesis ke tiga tersebut,setelah ditelaah dinyatakan bahwa variabel psikologi (X2) yang berpengaruh dominan terhadap kepuasan pasien (Y) berdasarkan hal ini maka hipotesis ketiga di tolak, karena variabel psikologi memiliki nilai Standardized Coefficients Beta 0,846 nilai ini lebih besar dibanding dengan nilai variabel lainnya.

\subsection{Pembahasan}

1. Faktor individu, faktor psikologi dan faktor organisasi berpengaruh signifikan secara parsial terhadap kinerja pegawai Satgas Kebersihan di Dinas Lingkungan Hidup Kabupaten Balangan.

Terkait dengan penelitian pada Satgas Kebersihan di Dinas Lingkungan Hidup Kabupaten Balangan yang mana selama ini pada pengujian hipotesis pertama diketahui bahwa hasil penelitian yang menguji secara parsial dinyatakan dan dibuktikan dalam penelitian ini bahwa faktor individu, faktor psikologi dan faktor organisasi berpengaruh signifikan secara parsial terhadap kinerja pegawai Satgas Kebersihan di Dinas Lingkungan Hidup Kabupaten Balangan, penelitian ini sejalan dengan hasil 
penelitian Muhammad Firdaus, (2016), analisis faktor-faktor yang mempengaruhi kinerja pegawai pada Puskesmas Pisangan Jakartayang menyatakan dalam penelitiannya bahwa faktor psikologi, faktor organisasi dan faktor individu dan hasilnya ketiga variabel berpengaruh signifikan terhadap kinerja pegawai secara parsial.

Berdasarkan hasil penelitian tersebut, maka hendaknya pihak Dinas Lingkungan Hidup Kabupaten Balangan dapat lebih memperhatikan dan mengembangkan kembali akan faktor individu, faktor psikologi dan faktor organisasi agar kinerja pegawai satgas dapat di optimalkan sesuai dengan harapan. Adapun upaya yang dapat dilakukan adalah:

Dinas Lingkungan Hidup Kabupaten Balangan perlu mengelola individu satgas dengan baik, sebagaimana pendapat Darmwan (2012:112), individu yang sangat berhati-hati dan penuh pertimbangan dalam melakukan suatu tindakan. Umumnya individu dengan karakter ini memiliki disiplin yang tinggi, rajin, dapat diandalkan, bertanggungjawab, serta bekerja dengan cermat dan terperinci, selain itu perlu mengelola aspek organik jasmaniah melalui pembinaan melalui olah raga bersama, aspek psikis-rohaniah pembinaan melalui siraman rohani dan aspek social pembinaan melalui pembentukan sikap dan loyalitas satgas melalui diklat integritas, dengan binanya ketiga aspek tersebut diharapkan dapat membantu satgas kebersihan bekerja lebih baik.

Dinas Lingkungan Hidup Kabupaten Balangan perlu mengelola psikologi satgas, sesuai pendapat Jarmain (2013:23) mempelajari tentang psikologi dapat memberikan manfaat yang baik bagi manusia, baik secara individu maupun kelompok dalam bekerja untuk itu pihak instansi perlu mengetahui akan mental baik normal maupun abnormal dan pengaruhnya terhadp perilaku pegawai/satgas agar dapat diketahui minat dan keinginan secara kejiwannya, sehingga akan mempermudah dalam membina satgas dalam bekerja.

Dinas Lingkungan Hidup Kabupaten Balangan perlu mengelola organisasi yang dapat mendukung kinerja satgas, sejalan pendapat Hasibuan (2012:90) pengertian organisasi adalah sebagai proses penentuan, pengelompokan, dan pengaturan bermacam-macam aktivitas yang diperlukan untuk mencapai tujuan bersama. Untuk itu pihak instansi perlu lebih baik lagi dalam mengelola organisasi satgas dengan cara membuat adanya peraturan kerja untuk mengatur dan membatasi sumberdaya yang dimiliki agar saling bersinergi dalam proses pencapaian tujuan dan menciptakan manajemen yang baik dalam organisas dan membuat pembagian tugas dan tanggungjawab dengan baik dan profesional.

2. Faktor individu, faktor psikologi dan faktor organisasi berpengaruh signifikan secara simultan terhadap kinerja pegawai Satgas Kebersihan di Dinas Lingkungan Hidup Kabupaten Balangan Terkait dengan penelitian pada Satgas Kebersihan di Dinas Lingkungan Hidup Kabupaten Balangan yang mana selama ini pada pengujian hipotesis kedua diketahui bahwa hasil penelitian yang menguji secara parsial dinyatakan dan dibuktikan dalam penelitian ini bahwa faktor individu, faktor psikologi dan faktor organisasi berpengaruh signifikan secara simultan terhadap kinerja pegawai Satgas Kebersihan di Dinas Lingkungan Hidup Kabupaten Balangan, hasil penelitian ini sejalan dengan penelitian Muhammad Firdaus, (2016), Analisis Faktor-Faktor Yang Mempengaruhi Kinerja Pegawai Pada Puskesmas Pisangan Jakarta. yang menyatakan bahwa faktor psikologi, faktor organisasi dan faktor individu dan hasilnya ketiga variabel berpengaruh signifikan terhadap kinerja pegawai baik secara simultan. Berdasarkan hasil penelitian tersebut, maka hendaknya pihak instansi perlu lebih meningkatkan kembali akan faktor inividu, psikologi maupun faktor organisasi guna membantu meningkatkan kinerja pegawai satgas kebersihan dalam bekerja.

Usaha yang perlu dilakukan guna meningkatkan faktor individu satgas adalah dengan (1) memahami akan kondisi jasmani satgas agar selalu sehat dengan mengajak 
mereka selalu hidup sehat dan berolahraga (2) mengelola individu satgas melalui pembentukan pola pikiran dan perasaan agar mereka dapat bekerja secara ikhlas dan dalam bekerja (3), perlu juga memperhatikan bakat dan keahlian satgas dalam bekerja kalau memang baik dalam bekerja hendaknya dapat di tingkatkan status mereka menjadi pegawai non kontrak atau pegawai tetap. Dengan demikian diharapkan kinerja pegawai satgas kebersihan dapat dioptimalkan sesuai harapan.

3. Faktor psikologi berpengaruh dominan terhadap kinerja pegawai Satgas Kebersihan di Dinas Lingkungan Hidup Kabupaten Balangan

Terkait dengan penelitian pada Satgas Kebersihan di Dinas Lingkungan Hidup Kabupaten Balangan yang mana selama ini pada pengujian hipotesis ketiga diketahui bahwa hasil penelitian secara dominan terbukti dalam penelitian ini bahwa faktor psikologi berpengaruh dominan terhadap kinerja pegawai Satgas Kebersihan di Dinas Lingkungan Hidup Kabupaten Balangan, hal ini sejalan dengan hasil tanggapan responden yang menyatakan sebagian besar bahwa faktor psikologi mempunyai pengaruh besar terhadap kinerja satgas, hal ini jelas secara kejiwaan atau mental lah yang mempunyai peran penting dalam meningkatkan kinerja satgas dan hal ini sesuai teori Syah (2012:9), yang menjelaskan faktor psikologi adalah pengetahuan yang mempelajari tentang tingkah laku terbuka (berbicara, duduk, berjalan, dan lainnya) dan tingkah laku tertutup (berfikir, berkeyakinan, berperasaan) pada manusia, baik selaku individu maupun kelompok, dalam hubungannya dengan lingkungan. Selain itu hasil penelitian ini sejalan dengan hasil penelitian Muhammad Firdaus, (2016) yang menyatakan dalam penelitiannya variabel yang dominan adalah faktor psikologi.

Berdasarkan hasil penelitian tersebut maka pihak instansi harus benar-benar dapat memperhatikan dan mengembangkan akan faktor psikologi dari para satgas kebersihan tersebut, aspek kejiwaan mereka dalam bekerja perlu mendapatkan perhatian yang lebih baik serta pihak pegawai yang berstatus PNS harus dapat menganggap para satgas ini sebagai pekerja/lebih manusiawi dengan selalu menghargai kerja mereka selain itu hak-haknya sebagai satgas kebersihan harus selalu diperhatikan dan ditingkatkan tanpa ada keterlambatan agar mereka dapat bekerja lebih baik lagi.

\section{PENUTUP \\ 6.1Kesimpulan}

Penelitian pada Satgas Kebersihan di Dinas Lingkungan Hidup Kabupaten Balangan pada pengujian hipotesis pertama diketahui bahwa hasil penelitian yang menguji secara parsial dinyatakan dan dibuktikan dalam penelitian ini bahwa faktor individu, faktor psikologi dan faktor organisasi berpengaruh signifikan secara parsial terhadap kinerja pegawai Satgas Kebersihan di Dinas Lingkungan Hidup Kabupaten Balangan Penelitian pada Satgas Kebersihan di Dinas Lingkungan Hidup Kabupaten Balangan pada pengujian hipotesis kedua diketahui bahwa hasil penelitian yang menguji secara parsial dinyatakan dan dibuktikan dalam penelitian ini bahwa faktor individu, faktor psikologi dan faktor organisasi berpengaruh signifikan secara simultan terhadap kinerja pegawai Satgas Kebersihan di Dinas Lingkungan Hidup Kabupaten Balangan Penelitian pada Satgas Kebersihan di Dinas Lingkungan Hidup Kabupaten Balangan pada pengujian hipotesis ketiga diketahui bahwa hasil penelitian yang menguji secara parsial dinyatakan dan dibuktikan dalam penelitian ini bahwa faktor psikologi berpengaruh dominan terhadap kinerja pegawai Satgas Kebersihan di Dinas Lingkungan Hidup Kabupaten Balangan, hal ini disebabkan hasil tanggapan responden lebih menekankan pada aspek kejiwaan yang dapat merubah perilaku seseorang dalam bekerja.

\subsection{Saran}

Dinas Lingkungan Hidup Kabupaten Balangan perlu mengelola individu satgas dengan pembinaan melalui olah raga bersama, pembinaan melalui siraman rohani dan pembinaan melalui diklat integritas, dengan binanya ketiga aspek 
tersebut diharapkan dapat membantu satgas kebersihan bekerja lebih baik.

Dinas Lingkungan Hidup Kabupaten Balangan perlu mengelola psikologi satgas, dalam hal ini pihak instansi perlu mengetahui akan pengetahuan yang berhubungan dengan proses mental, baik normal maupun abnormal dan pengaruhnya terhadp perilaku pegawai/satgas. Psikologi dapat juga didefinisikan sebagai ilmu pengetahuan tentang gejala dan kegiatan jiwa bagi satgas, sehingga akan mempermudah dalam membina satgas dalam bekerja.

Dinas Lingkungan Hidup Kabupaten Balangan perlu mengelola organisasi yang dapat mendukung kinerja satgas, organisasi sebagai proses penentuan, pengelompokan, dan pengaturan bermacam-macam aktivitas yang diperlukan untuk mencapai tujuan bersama, untuk itu pihak instansi perlu lebih baik lagi dalam mengelola organisasi satgas dengan cara membuat adanya peraturan kerja yang jelas, menciptakan organisas simpel namun dapat berjalan optimal dan membuat pembagian tugas dan tanggungjawab secara profesional.

Faktor psikologi berpengaruh dominan terhadap kinerja pegawai Satgas Kebersihan di Dinas Lingkungan Hidup Kabupaten Balangan, berdasarkan hasil penelitian tersebut, pihak instansi harus benar-benar dapat memperhatikan dan mengembangkan akan faktor psikologi dari para satgas kebersihan tersebut, aspek kejiwaan mereka dalam bekerja perlu mendapatkan perhatian yang lebih baik serta pihak pegawai yang berstatus PNS harus dapat menganggap para satgas ini sebagai pekerja/lebih manusiawi dengan selalu menghargai kerja mereka selain itu hak-haknya sebagai satgas kebersihan harus selalu diperhatikan dan ditingkatkan tanpa ada keterlambatan agar mereka dapat bekerja lebih baik lagi.

\section{DAFTAR PUSTAKA}

As'ad, 2011, Manajemen Perusahaan, Rineka Cipta, Jakarta

Arikunto, Suharsimi, 1990. Prosedur Penelitian. Rineka Cipta. Jakarta
1992. Prosedur

Penelitian. Edisi Revisi, Rineka Cipta. Jakarta

2002. Riset dan

Program SPSS Penelitian Paramedik,

Rineka Cipta. Jakarta

Dewantara, 2011, Manajemen Sumber

Daya Manusia, Pustaka Karya, Jakarta

Dessler, Gary, 2000, Manajemen Sumber

Daya Manusia. Jilid I. Prenhallindo. Jakarta 2007, Manajemen Sumber

Daya Manusia. Jilid III. Prenhallindo. Jakarta

Erwinda, 2010, Pengaruh Pengaruh Faktor Kinerja Melalui Faktor Pengembangan Karier, Tekanan Pekerjaan, Pimpinan, Individu dan Kompensasi terhadap Kinerja Pegawai pada Dinas Koperasi dan UKM Kabupaten Balangan, Unlam, Banjarmasin Efendi, 2002, Manajemen Perusahaan, Andy, Yogyakarta

Erwin, 2011, Manajemen Perkantoran dan Perilaku Keorganisasian, Bumi Aksara, Jakarta

Evalia, 2010, Manajemen, Liberti, Jakarta

Gomes. Faustino.C, 2000, Manajemen Sumber Daya Manusia, Edisi Revisi, Penerbit Andi, Yogyakarta

Guritno Bambang dan Waridin, 2005, Manajemen Perusahaan, Bumi Aksara, Jakarta

Handoko, T. Hani, 2001. Manajemen Personalia dan Sumber Daya Manusia. Yogyakarta : BPFE-Yogyakarta.

2011. Manajemen

Personalia dan Sumber Daya Manusia, Edisi Revisi, Yogyakarta : BPFEYogyakarta

Lukman Hakim, 2012, Analisis Faktor Kinerja Pegawai terhadap Kinerja Pegawai pada kantor Samsat Kota Banjarmasin, Unlam, Banjarmasin

Muhammad Firdaus, 2016, Analisis Faktorfaktor Yang Mempengaruhi Kinerja Pegawai Pada Puskesmas Pisangan Jakarta, Universitas Gunadarma, Jakarta Mangkunegara, 2012, Manajemen, SDM, Rajawali Press, Jakarta Muchtar, 2011. Manajemen SDM, Penerbit PT. Remaja Rosdakarya. Bandung 
Mulyanto, 2013, Manajemen Perusahaan, Intan Media, Surabaya

Pratisto, 2004. Metode Penelitian Untuk

Skripsi dan Tesis Bisnis. PT.

Rajagrafindo Persada, Jakarta

Rita Swetenia, 2009, Perilaku dan

Keorganisasian, Rineka Cipta, Jakarta

Rivai. V, 2009, Manajemen Sumber Daya

Manusia. Salemba Empat, Jakarta

Robert L. Mathis \& Jhon H. Jackson, 2002,

Organizational Behavior, Concept

Controversies, Aplications Seventh Edition

(Prentice Hall International1996) p.681-

2.tags

Robbins, 2010, Human Resource Management,Boston: Allyn and Dacon

Supranto, 1995, Metode Penelitian dan Stasistik, PT. Rawjawali Press, Jakarta

Sutrisno, 2010. Manajemen Sumber Daya Manusia Untuk Perusahaan. Murai Kencana, Jakarta

Simamora, Henry. 2004. Manajemen Sumber Daya Manusia, Edisi Ke II, STIEYKPN Yogyakarta

Srimulyo, 1999, Evaluasi Perilaku Individu Dalam Organisasi, Global, Jakarta

Suhardjito, 2009, Pengantar Ilmu Manajemen, Balai Psutaka, Jakarta

Sudarmadji, 2011, Manajemen Sumber Daya Manusia, Rajawali Press, Jakarta

Setiawan, 2012, Ilmu Manajemen, Pustaka, Jakarta

Shandy, 2012, Manajemen Perusahaan, Bumi Aksara, Jakarta

Solimun, 2004, Metode Penelitian, Rineka Cipta, Jakarta

Sulastri, 2013, Analisis Faktor Kinerja Pegawai Pada Dinas Kehutanan Propinsi Kalimantan Selatan, Unlam, Banjarmasin

Sulistyo. Joko, 2002, 6 Hari Jago SPSS 17, Cakrawala, Jakarta

Winardi, 2002, Azaz-azaz Manajemen, Nova, Bandung

Wibowo, 2011, Keorganisasi, Rineka Cipta, Jakarta 